\title{
Synthesis and biological activity of novel benzoazoles, benzoazines and other analogs functionalized by 2,4-dihydroxyphenyl moiety
}

\author{
Joanna Matysiak ${ }^{1}$ (D) Alicja Skrzypek ${ }^{1} \cdot$ Urszula Głaszcz $^{1}$ • \\ Arkadiusz Matwijczuk ${ }^{2} \cdot$ Bogdan Senczyna $^{1} \cdot$ Joanna Wietrzyk $^{3}$. \\ Elżbieta Krajewska-Kułak ${ }^{4}$ Andrzej Niewiadomy ${ }^{1,5}$
}

Received: 8 December 2017/ Accepted: 22 May 2018/Published online: 31 May 2018

(C) The Author(s) 2018

\begin{abstract}
Novel benzoazoles, benzoazines, benzothiazoles, benzothiazines and other related compounds possessing a 2,4-dihydroxyphenyl moiety were prepared. The compounds were obtained by the reaction of sulfinylbis[(2,4-dihydroxyphenyl)methanethione]s with the appropriate heterocyclic amines or hydrazines. The structures of the compounds were proved by IR, ${ }^{1} \mathrm{H}$ NMR, and mass spectral data. Human cancer lines, Candida species and phytopathogenic fungi were used for the evaluation of biological potency of compounds. Additionally, drug-like properties were estimated in silico.
\end{abstract}

Keywords Benzothiazine $\cdot$ Benzothiazole $\cdot$ Benzoazine $\cdot$ Antiproliferative activity $\cdot$ Antifungal activity

Joanna Matysiak

joanna.matysiak@up.lublin.pl

1 Department of Chemistry, University of Life Sciences in Lublin, Akademicka 15,

20-950 Lublin, Poland

2 Department of Biophysics, University of Life Sciences in Lublin, Akademicka 13, 20-950 Lublin, Poland

3 Department of Experimental Oncology, Institute of Immunology and Experimental Therapy, Polish Academy of Sciences, R. Weigla 12, 53-114 Wrocław, Poland

4 Department of Integrated Medical Care, Medical University, ul. M. Skłodowskiej-Curie 7A, Białystok, Poland

5 Institute of Industrial Organic Chemistry, Annopol 6, 03-236 Warsaw, Poland 


\section{Introduction}

Nitrogen and sulfur heterocycles have received a great deal of attention in the literature due to their role as active pharmacophores. Benzothiazines are a group of bioactive compounds known to have anticancer, diuretic, and anti-hypertensive activities [1, 2]. The representatives of this heterocyclic class are assumed to possess biological activities since they might provide the heteroatoms as potential hydrogen bond acceptors and the fused phenyl ring for possible $\pi-\pi$ interactions. In particular, 1,2-benzothiazine and 1,3-benzothiazine derivatives have exhibited promising pharmacological properties: anti-inflammatory, antitumor and antiproliferative activity [3, 4], as well as antomicrobial activity [5-8]. 4H-1,4-benzothiazines exhibited antifungal potency against Aspergillus fumigates and Candida albicans $[9,10]$. The derivatives of $12(H)$-quino[3,4- $b][1,4]$ benzothiazine showed antiproliferative activity against two cancer cell lines, SNB-19 and C-32 [11], while 6-substituted 9-fluoroquino[3,2-b]benzo[1,4]thiazines exhibited cytotoxicity as well as antiproliferative actions against human peripheral blood mononuclear cells stimulated with phytohemagglutinin A (PHA) [12].

Coupling of 2-alkylthiobenzimidazole with the $\beta$-lactam ring produced compounds with antibacterial and antifungal activities [13]. Attachment of other heterocycles like $\beta$-lactam, thiadiazole and oxadiazole to the benzimidazole skeleton resulted in hybrid compounds of potent antibacterial and/or antifungal properties [14-16]. A pyridobenzimidazole derivative with unique activities, called D75-4590, is a specific inhibitor of $\beta-1,6$-glucan synthesis and exhibits potent activities against various Candida species [17]. The series of methyl-4H-1benzopyran-4-ones carrying mono- or diamidinobenzimidazoles at different positions have been described for antibacterial and antifungal activities [18]. Methylbenzimidazoles are an important class of compounds for cytotoxic activity against human tumour cell lines [19].

Recently, there have been various approaches to study the role of the benzothiazole moiety as antimicrobial [20-23], anticancer [24-27] and antifungal agents [22, 28-30]. It has been shown that some benzothiazole dimers were free from irritation, teratogenicity and sensitivity properties compared to monomers and that the increase in the hydrogen donor count is conductive for cytotoxic activity of derivatives against the HL-60 cell lines [31]. The novel N-alkylbromobenzothiazoles have been evaluated for their anticancer potency [32]. The derivatives of imidazo[2,1-b][1,3]benzothiazole have been reported for their strong inhibitory activity against bacterial and fungal strains [33].

Modifications on the heterocycle nucleus resulted in a large number of compounds characterized by diverse pharmacological activities. The biological profiles of new generations of benzothiazoles, benzimidazoles and benzthiazines represent much progress as regards the older compounds. Looking into the medicinal importance of these compounds' moiety, it was thought worth synthesizing some newer derivatives and screening them for their biological activities. 
To extend our studies in this area, a set of new heterocyclic analogs with 2,4dihydroxyphenyl functionality were designed and obtained. Following from previous studies, this group of compounds exhibits strong antifungal and antiproliferative activity [34-39]. This paper presents the in vitro antifungal potency of compounds against the panel phytopathogenic fungi and Candida strains as well as cytotoxic potency against human cancer cell lines. Some properties of compounds in silico were estimated to explain the influence of the structure of the compounds on their biological properties.

\section{Experimental}

\section{Chemistry}

\section{General}

Melting points (m.p.) were determined using a BÜCHI B-540 (Flawil, Switzerland) melting point apparatus. The elemental analysis $(\mathrm{C}, \mathrm{H}, \mathrm{N})$ was performed on a Perkin-Elmer 2400. The IR spectra were measured with a Perkin-Elmer FT-IR $1725 \mathrm{X}$ spectrophotometer (in $\mathrm{KBr}$ ) or a Varian 670-IR FT-IR spectrometer (ATR) in the range of $600-4000 \mathrm{~cm}^{-1}$. The NMR spectra (1D NMR) were recorded in DMSO- $d_{6}$ using a Varian Mercury 400, Bruker DRX 500 (Bruker Daltonics, Billerica, MA, USA) or Tesla BS 567A (100 MHz). Chemical shifts $(\delta$, ppm) have been described in relation to tetramethylsilane and coupling constants $(J)$ are expressed in Hz. The MS spectra (EI, $70 \mathrm{eV}$ ) were recorded using the apparatus AMD-604.

The purity of the compounds was examined by HPLC Knauer (Berlin, Germany) with a dual pump, a $20-\mu \mathrm{L}$ simple injection valve and a UV-visible detector (275 and $330 \mathrm{~nm})$. The Hypersil Gold C18 $(1.9 \mu \mathrm{m}, 100 \times 2.1 \mathrm{~mm})$ column was used as the stationary phase. The mobile phase included different contents of $\mathrm{MeOH}$ and the aqueous phase (acetate buffer, $\mathrm{pH} 4,20 \mathrm{nM}$ ). The flow rate was $0.4 \mathrm{ml} / \mathrm{min}$ at room temperature. The retention time of an unretained solute $\left(\mathrm{t}_{\mathrm{o}}\right)$ was determined using $\mathrm{KCl}$. The $\log k$ values for 80 or $65 \%$ of $\mathrm{MeOH}(\mathrm{v} / \mathrm{v})$ in the mobile phase are presented. They were calculated as $\log k=\log \left(t_{\mathrm{R}}-t_{\mathrm{o}}\right) / t_{\mathrm{o}}$, where $t_{\mathrm{R}}$ is the retention time of a solute, and $t_{\mathrm{o}}$ the retention time of an unretained solute.
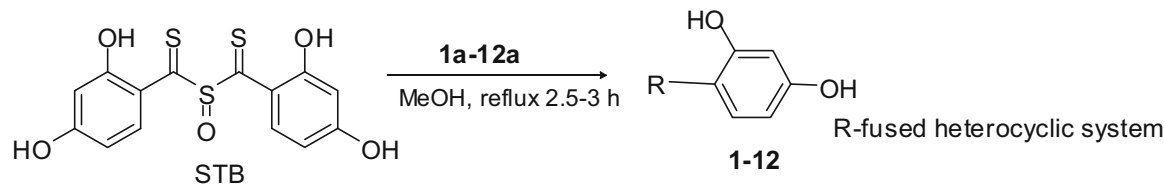

Fig. 1 Synthesis scheme of compounds 1-12 


\section{General procedure for the synthesis of compounds 1-12}

A mixture of the corresponding amine or hydrazine $(5 \mathrm{mmol})(\mathbf{1 a}-\mathbf{1 2 a})$ and STB (10 mmol) in $\mathrm{MeOH}(80 \mathrm{~mL})$ (Fig. 1) was heated to reflux for $2.5-3 \mathrm{~h}$. The hot mixture was filtered via a Büchner funnel. Next, the formed solid was filtered off (2, 9-11), and either the filtrate was concentrated (compounds 3-8) or water was added to afford the solid $(\mathbf{1}, \mathbf{1 2})$ which was filtered. Finally, the product was recrystallized from $\mathrm{MeOH}$ (compounds 1, 2, 5, 9, 10), from $\mathrm{MeOH} / \mathrm{H}_{2} \mathrm{O}(3: 1)(\mathbf{4}, \mathbf{1 1})$ or from $\mathrm{MeOH} / \mathrm{H}_{2} \mathrm{O}(2: 1)(\mathbf{3}, \mathbf{6}-\mathbf{8}, \mathbf{1 2})$, respectively.

2-(2,4-Dihydroxyphenyl)-9b-methoxy-[1,3,4]thiadiazolo[2,3-a]isoindol-5(9bH)-one

1 IR (KBr) $v_{\max }: 3460(\mathrm{OH}), 3024(\mathrm{C}(\mathrm{Ar})-\mathrm{H}), 2950(\mathrm{CH}), 1702(\mathrm{C}=\mathrm{O}), 1661$ $(\mathrm{C}=\mathrm{N}), 1623(\mathrm{C}=\mathrm{N}), 1604(\mathrm{C}=\mathrm{C}), 1576(\mathrm{C}=\mathrm{C}), 1521(\mathrm{C}=\mathrm{C}), 1494,1472,1452$, 1435, 1349, 1322, 1302, 1280, 1217 (C-OH), 1181, 1141, 1123, 1096, 1024, 997, $985,969,871,829,804,795,759,729,714 \mathrm{~cm}^{-1} ;{ }^{1} \mathrm{H}$ NMR (500 MHz, DMSO- $\left.d_{6}\right)$ $\delta: 11.14$ (s, $1 \mathrm{H}, \mathrm{HO}-\mathrm{C}-(2)), 10.08$ (s, $1 \mathrm{H}, \mathrm{HO}-\mathrm{C}(4)), 8.08$ (d, J = 8.7 Hz, $1 \mathrm{H}, \mathrm{H}-$ $\mathrm{C}(6)), 7.89(\mathrm{~m}, 1 \mathrm{H}, \mathrm{H}-\mathrm{C}(\mathrm{Ar})), 7.80(\mathrm{~m}, 1 \mathrm{H}, \mathrm{H}-\mathrm{C}(\mathrm{Ar})), 7.72(\mathrm{td}, J=7.5$ and $1.5 \mathrm{~Hz}, 1 \mathrm{H}, \mathrm{H}-\mathrm{C}(\mathrm{Ar})), 7.68(\mathrm{td}, J=7.5$ and $1.4 \mathrm{~Hz}, 1 \mathrm{H}, \mathrm{H}-\mathrm{C}(\mathrm{Ar})), 6,51$ (d, $J=2.3 \mathrm{~Hz}, 1 \mathrm{H}, \mathrm{H}-\mathrm{C}(3)), 6.46(\mathrm{dd}, J=8.7$ and $2.3 \mathrm{~Hz}, 1 \mathrm{H}, \mathrm{H}-\mathrm{C}(5)), 3.71$ (s, $3 \mathrm{H}$, $\left.\mathrm{CH}_{3}\right) \mathrm{ppm} ;{ }^{13} \mathrm{C}$ NMR $\left(125 \mathrm{MHz}, \mathrm{DMSO}-d_{6}\right) \delta: 167.7(\mathrm{C}=\mathrm{O}), 164.2,163.5,161.3$, 156.4, 131.6, 131.5, 130.8, 130.3, 129.3, 129.0, 128.9, 108.4, 108.2, 102.3, 52.3 $\left(\mathrm{CH}_{3}\right)$ ppm; EI-MS (m/z, \%): $328\left(\mathrm{M}^{+}, 48\right), 296$ (72), 268 (3), 162 (100), 149 (5), 132 (23), 130 (14), 119 (2), 104 (70), 102 (3), 90 (2), 76 (18), 63 (2), 51 (10), 40 (7).

4-(4-Hydroxy-6-methyl-4-phenyl-4H-benzo[d][1,3]thiazin-2-yl)benzene-1,3-diol 2 IR (ATR) $v_{\max }: 3251(\mathrm{OH}), 2942,1618(\mathrm{C}=\mathrm{N}), 1593(\mathrm{C}=\mathrm{C}), 1531,1490,1445(\mathrm{C}-$ H), 1340, 1257, 1209 (C-OH), 1182, 1128, 1053, 1019, 982, 920, 882, 845, 810, 746, 697, $654 \mathrm{~cm}^{-1}$; ${ }^{1} \mathrm{H}$ NMR (500 MHz, DMSO- $\left.d_{6}\right) \delta$ : 14.55 (s, $1 \mathrm{H}, \mathrm{HO}-\mathrm{C}$ (thiazine), 11.82 (s, 1 H, HO-C(3)), 10.90 (s, 1 H, HO-C(1)), 7.85 (d, J = 9.0 Hz, 1 H, H$\mathrm{C}(\mathrm{Ar})), 7.74$ (m, $1 \mathrm{H}, \mathrm{H}-\mathrm{C}(\mathrm{Ar})), 7.57$ (m, $2 \mathrm{H}, \mathrm{H}-\mathrm{C}(\mathrm{Ar})), 7.49$ (d, J = 8.77 Hz, $1 \mathrm{H}$, $\mathrm{H}-\mathrm{C}(\mathrm{Ar})), 7.40(\mathrm{~m}, 2 \mathrm{H}, \mathrm{H}-\mathrm{C}(\mathrm{Ar})), 7.25$ (m, $1 \mathrm{H}, \mathrm{H}-\mathrm{C}(\mathrm{Ar})), 6.45(\mathrm{~d}, J=8.2 \mathrm{~Hz}, 1 \mathrm{H}$, $\mathrm{H}-\mathrm{C}(\mathrm{Ar})), 6.37$ (m, $2 \mathrm{H}, \mathrm{H}-\mathrm{C}(\mathrm{Ar})), 1.70$ (s, $\left.3 \mathrm{H}, \mathrm{CH}_{3}\right) \mathrm{ppm} ;{ }^{13} \mathrm{C} \mathrm{NMR}(125 \mathrm{MHz}$, DMSO-d $d_{6} \delta$ : 207.8, 164.7, $163.0162 .9,162.6,140.5,139.5,136.3,129.9,129.7$, 128.6, 128.1, 126.3, 119.6, 114.3, 110.9, 108.7, 107.9, 103.2, 57.9, $19.5\left(\mathrm{CH}_{3}\right) \mathrm{ppm}$; $\operatorname{ESI-MS~(m/z):~} 362.1\left[[\mathrm{M}-\mathrm{H}]^{-}\right]$.

4-(Perfluorobenzo[d]thiazol-2-yl)benzene-1,3-diol 3 IR (KBr) $v_{\max }: 3445(\mathrm{OH})$, $3350(\mathrm{OH}), 1626(\mathrm{C}=\mathrm{N}), 1595(\mathrm{C}=\mathrm{N}), 1497(\mathrm{C}=\mathrm{C}), 1493,1333,1291,1256,1228$ (C-OH), 1173, 1139 (C-F), 1090, 1041, 1013, 980, 946, 876, 794, $749 \mathrm{~cm}^{-1} ;{ }^{1} \mathrm{H}$ NMR (100 MHz, DMSO- $\left.d_{6}\right) \delta$ : 11.39 (s, 1 H, HO-C(3) (exchangeable in $\left.\mathrm{D}_{2} \mathrm{O}\right)$ ), 10.31 (s, $1 \mathrm{H}, \mathrm{HO}-\mathrm{C}(1)$ (exchangeable in $\left.\mathrm{D}_{2} \mathrm{O}\right)$ ), 8.05 (d, $\left.J=8.7 \mathrm{~Hz}, 1 \mathrm{H}, \mathrm{H}-\mathrm{C}(5)\right)$, $6.51(\mathrm{~d}, J=2.3 \mathrm{~Hz}, 1 \mathrm{H}, \mathrm{H}-\mathrm{C}(2)), 6.49$ (m, $1 \mathrm{H}, \mathrm{H}-\mathrm{C}(6)) \mathrm{ppm}$; EI-MS (m/z, \%): $315\left(\mathrm{M}^{+}, 100\right), 259$ (7), 258 (32), 226 (4), 144 (6), 69 (3), 40 (5).

4-(6-Amino-5-chlorobenzo[d]thiazol-2-yl)benzene-1,3-diol 4 IR (KBr) $v_{\max }$ : 3443 $(\mathrm{OH}), 3383(\mathrm{OH}), 2928(\mathrm{CH}), 2850(\mathrm{CH}), 1628(\mathrm{C}=\mathrm{N}), 1591(\mathrm{C}=\mathrm{N}), 1543(\mathrm{C}=\mathrm{C})$, $1511(\mathrm{C}=\mathrm{C}), 1470,1384,1345,1277,1230,1121(\mathrm{C}-\mathrm{OH}), 1178(\mathrm{C}-\mathrm{Cl}), 991,871$, 
853, 794, $728 \mathrm{~cm}^{-1} ;{ }^{1} \mathrm{H}$ NMR (500 MHz, DMSO- $\left.d_{6}\right) \delta: 11.86$ (s, $1 \mathrm{H}, \mathrm{HO}-\mathrm{C}(3)$ ), 10.37 (s, 1 H, HO-C(1)), 8.30 (s, $1 \mathrm{H}, \mathrm{H}-\mathrm{C}($ benzothiazole)), 8.21 (m, $2 \mathrm{H}, \mathrm{H}-$ $\mathrm{C}($ benzothiazole)), H-C(5)), 6.42 (m, $2 \mathrm{H}, \mathrm{H}-\mathrm{C}(2,6)) \mathrm{ppm} ;{ }^{13} \mathrm{C}$ NMR (125 MHz, DMSO- $\left.d_{6}\right) \delta$ : 162.2, 147.2, 135.9, 134.4, 130.1, 128.7, 127.3, 115.8, 112.3 108.1, 106.5, 102.6, 99.5 ppm; EI-MS (m/z, \%): $292\left(\mathrm{M}^{+}, 100\right), 258$ (5), 223 (6), 176 (18), 153 (30), 147 (5), 124 (4), 97 (6), 69 (5), 53 (3).

4-(5-(5-(2,4-Dihydroxyphenyl)-1,3,4-thiadiazol-2-yl)-1H-benzo[d]imidazol-2-yl)benzene-1,3-diol 5 IR (ATR) $v_{\max }: 3402(\mathrm{OH}), 3134(\mathrm{OH}), 2940(\mathrm{OH}), 1631(\mathrm{C}=\mathrm{N})$, $1598(\mathrm{C}=\mathrm{C}), 1525(\mathrm{C}=\mathrm{C}), 1496,1469,1424,1315,1301,1257(\mathrm{C}-\mathrm{OH}), 1163,1139$, 1107, 1050, 1018, 981, 964, 846, 800, 752, 691, 659, $633 \mathrm{~cm}^{-1} .1 \mathrm{H} \mathrm{NMR}$ $\left(400 \mathrm{MHz}, \mathrm{DMSO}-d_{6}\right) \delta: 11.56(\mathrm{~s}, 1 \mathrm{H}, \mathrm{OH}), 11.28(\mathrm{~s}, 1 \mathrm{H}, \mathrm{OH}), 10.82$ (s, $1 \mathrm{H}$, $\mathrm{OH}), 10.17$ (s, $1 \mathrm{H}, \mathrm{OH}), 8.39$ (d, $J=1.7 \mathrm{~Hz}, 1 \mathrm{H}, \mathrm{H}-\mathrm{C}($ benzoimidazole)(4)), 8.10 $(\mathrm{m}, 3 \mathrm{H}, \mathrm{H}-\mathrm{C}(\mathrm{Ar})), 7.91(\mathrm{~d}, J=8.4 \mathrm{~Hz}, 1 \mathrm{H}, \mathrm{H}-\mathrm{C}(6)), 6.75(\mathrm{~d}, J=2.2 \mathrm{~Hz}, 1 \mathrm{H}, \mathrm{H}-$ $\mathrm{C}(3)), 6.59(\mathrm{~m}, 2 \mathrm{H}, \mathrm{H}-\mathrm{C}(2,6)), 6.48(\mathrm{dd}, J=8.7$ and $2.2 \mathrm{~Hz}, 1 \mathrm{H}, \mathrm{H}-\mathrm{C}(5)) \mathrm{ppm}$; ${ }^{13} \mathrm{C}$ NMR (125 MHz, DMSO- $\left.d_{6}\right) \delta: 164.7,161.1,160.3,157.3,156.6,155.6,132.0$, $130.8,130.6,129.3,127.7,121.2$, 120.7, 120.6, 118.9, 112.4, 112.2, 108.6, 108.5, 102.6, $56.1 \mathrm{ppm}$; ESI-MS (m/z): $419[\mathrm{M}+\mathrm{H}]^{+}$.

4-(5,7,8-Trifluoro-1H-benzo[e][1,3,4]thiadiazin-3-yl)benzene-1,3-diol 6 IR (KBr) $v_{\max }: 3223(\mathrm{OH}), 3088(\mathrm{H}-\mathrm{C}(\mathrm{Ar})), 1653(\mathrm{C}=\mathrm{N}), 1615(\mathrm{C}=\mathrm{C}), 1516(\mathrm{C}=\mathrm{C}), 1488$, 1464, 1416, 1395, 1373, 1315, 1262, 1225 (C-OH), 1180, 1168, 1116, 1076, 985, 948, 920, 844, 825, 816, 777, $712 \mathrm{~cm}^{-1} ;{ }^{1} \mathrm{H}$ NMR (500 MHz, DMSO- $\left.d_{6}\right) \delta: 11.93$ (s, 1 H, HO-C(3)), 10.18 (s, 1 H, HO-C(1)), 8.92 (s, 1 H, NH), 7.89 (d, J = 9.4 Hz, $1 \mathrm{H}, \mathrm{H}-\mathrm{C}(5)), 7.24$ (m, $1 \mathrm{H}, \mathrm{H}-\mathrm{C}($ benzothiadiazine $)), 6.37$ (m, $2 \mathrm{H}, \mathrm{H}-\mathrm{C}(2,6))$ ppm; ${ }^{13} \mathrm{C}$ NMR (125 MHz, DMSO- $\left.d_{6}\right) \delta: 192.0,162.1,157.8,146.8,144.9,138.0$, 135.9, 133.3, 127.3 113.9, 107.9, 102.9, 96.5 ppm; EI-MS (m/z, \%): $312\left(\mathrm{M}^{+}, 100\right)$, 260 (8), 187 (61), 165 (86), 153 (27), 150 (49), 135 (89), 108 (22), 99 (13), 88 (7), 80 (12), 69 (16), 52 (16), 39 (11).

4-(5,6,7,8-Tetrafluoro-1H-benzo[e][1,3,4]thiadiazin-3-yl)benzene-1,3-diol 7 IR $(\mathrm{KBr}) v_{\max }: 3234(\mathrm{OH}), 1622(\mathrm{C}=\mathrm{N}), 1521(\mathrm{C}=\mathrm{C}), 1464,1404,1347,1225(\mathrm{C}-$ $\mathrm{OH}), 1173,1125,1023,985,842,811,737,712 \mathrm{~cm}^{-1} ;{ }^{1} \mathrm{H}$ NMR $(500 \mathrm{MHz}$, DMSO- $\left.d_{6}\right) \delta: 11.96$ (s, $\left.1 \mathrm{H}, \mathrm{HO}-\mathrm{C}(3)\right), 10.11$ (s, $\left.1 \mathrm{H}, \mathrm{HO}-\mathrm{C}(1)\right), 8.83$ (s, $\left.1 \mathrm{H}, \mathrm{NH}\right)$, $7.82(\mathrm{~d}, J=9.4 \mathrm{~Hz}, 1 \mathrm{H}, \mathrm{H}-\mathrm{C}(5)), 6.35$ (d, $J=2.3 \mathrm{~Hz}, 1 \mathrm{H}, \mathrm{H}-\mathrm{C}(2)), 6.33$ (m, $1 \mathrm{H}$, H-C(6)) ppm; EI-MS (m/z, \%): 330 (M+1 100), 318 (6), 312 (7), 243 (3), 196 (52), 183 (54), 168 (54), 155 (24), 153 (24), 135 (100), 124 (13), 108 (29), 99 (10), 80 (14), 77 (6), 69 (23), 63 (9), 52 (19), 44 (11), 39 (14).

4-(6,8-Dichloro-1H-benzo[e][1,3,4]thiadiazin-3-yl)benzene-1,3-diol 8 IR (KBr) $v_{\max }: 3397(\mathrm{OH}), 3214(\mathrm{OH}), 3063(\mathrm{C}(\mathrm{Ar})-\mathrm{H}), 1626(\mathrm{C}=\mathrm{N}), 1601(\mathrm{C}=\mathrm{C}), 1509$ $(\mathrm{C}=\mathrm{C}), 1447,1382,1352,1332,1265,1231(\mathrm{C}-\mathrm{OH}), 1179,1127,1106,1077,986$, 944, 887, 861, 851, 824, 799, 774, $725 \mathrm{~cm}^{-1} ;{ }^{1} \mathrm{H}$ NMR (100 MHz, DMSO-d $\left.d_{6}\right) \delta$ : $12.10\left(\mathrm{~s}, 1 \mathrm{H}, \mathrm{HO}-\mathrm{C}(3)\right.$ (exchangeable in $\left.\mathrm{D}_{2} \mathrm{O}\right)$ ), 10.21 (s, $1 \mathrm{H}, \mathrm{HO}-\mathrm{C}(1)$ (exchangeable in $\left.\mathrm{D}_{2} \mathrm{O}\right)$ ), $8.05(\mathrm{~d}, 1 \mathrm{H}, \mathrm{H}-\mathrm{C}(5)), 7.50(\mathrm{~m}, 2 \mathrm{H}, \mathrm{H}-\mathrm{C}$ (benzothiadiazine) $(6,8)), 6.38(\mathrm{~m}, 2 \mathrm{H}, \mathrm{H}-\mathrm{C}(2,6)) \mathrm{ppm} ;{ }^{13} \mathrm{C}$ NMR $\left(125 \mathrm{MHz}, \mathrm{DMSO}-d_{6}\right) \delta$ : $161.7,157.1,152.3,146.3,138.7,134.0,128.7,126.4,124.5,113.2$, 109.3, 107.9, 
102.6 ppm; EI-MS (m/z, \%): 327 (M $\left.\mathrm{M}^{+}, 84\right), 294$ (3), 210 (4), 195 (37), 167 (9), 158 (9), 153 (100), 136 (21), 124 (7), 108 (5), 97 (8), 69 (5), 63 (4), 52 (5), 39 (4).

2-(2,4-Dihydroxyphenyl)-4H-benzo[d][1,3]thiazin-4-one 9 (previously the compound was obtained from 2-aminobenzanilide [5])

4-(1H-Perimidin-2-yl)benzene-1,3-diol $10 \quad \mathrm{IR}(\mathrm{KBr}) v_{\max }: 3412(\mathrm{OH}), 3057$ (C(Ar)-H), $2846(\mathrm{CH}), 1622(\mathrm{C}=\mathrm{N}), 1533(\mathrm{C}=\mathrm{C}), 1482,1446,1300,1229$ (C$\mathrm{OH}), 1150,1032,891,843,815,791,717 \mathrm{~cm}^{-1} ;{ }^{1} \mathrm{H}$ NMR (500 MHz, DMSO- $\left.d_{6}\right) \delta$ : 12.60 (s (broad), 2 H, H-C(1, 3), 10.39 (s, $1 \mathrm{H}, \mathrm{NH}), 7.73$ (d, J = 8.7 Hz, $1 \mathrm{H}, \mathrm{H}-$ $\mathrm{C}(5)), 7.25$ (m, $4 \mathrm{H}, \mathrm{H}-\mathrm{C}(\mathrm{Ar})), 6.80$ (m, $2 \mathrm{H}, \mathrm{H}-\mathrm{C}(\mathrm{Ar})), 6.47$ (d, J = 2.1 Hz, $1 \mathrm{H}$, $\mathrm{H}-\mathrm{C}(2)), 6.44(\mathrm{dd}, J=8.7$ and $2.3 \mathrm{~Hz}, 1 \mathrm{H}, \mathrm{H}-\mathrm{C}(6)) \mathrm{ppm}$; EI-MS (m/z, \%): 276 $\left(\mathrm{M}^{+}, 100\right), 247$ (6), 229 (4), 219 (15), 206 (27), 166 (5), 152 (3), 140 (7), 138 (5), 115 (7), 88 (3), 69 (2), 63 (3), 51 (2), 39 (2), 36 (6).

4-(Benzimidazo[1,2-c]chinazolin-6-yl)benzene-1,3-diol 11 IR (KBr): $v_{\max }=3273$ $(\mathrm{OH}), 1640(\mathrm{C}=\mathrm{N}), 1620(\mathrm{C}=\mathrm{N}), 1600(\mathrm{C}=\mathrm{C}), 1521(\mathrm{C}=\mathrm{C}), 1449,1341,1301,1230$, 1193, 1120, 979, 818, $771 \mathrm{~cm}^{-1} ;{ }^{1} \mathrm{H}$ NMR (100 MHz, DMSO- $\left.d_{6}\right) \delta: 10.03(\mathrm{~s}, 1 \mathrm{H}$, HO-C(3)), 9.93 (s, 1 H, HO-C(1)), 8.65 (dd, $J=7.9$ and $1.3 \mathrm{~Hz}, 1 \mathrm{H}, \mathrm{H}-\mathrm{C}(\mathrm{Ar})$ ), $7.97(\mathrm{dd}, J=7.9$ and $1.1 \mathrm{~Hz}, 1 \mathrm{H}, \mathrm{H}-\mathrm{C}(\mathrm{Ar})), 7.93(\mathrm{~d}, J=8.1 \mathrm{~Hz}, 1 \mathrm{H}, \mathrm{H}-\mathrm{C}(5))$, $7.89(\mathrm{td}, J=8.3$ and $1.5 \mathrm{~Hz}, 1 \mathrm{H}, \mathrm{H}-\mathrm{C}(\mathrm{Ar})), 7.77(\mathrm{td}, J=8,1$ and $1.1 \mathrm{~Hz}, 1 \mathrm{H}, \mathrm{H}-$ $\mathrm{C}(\mathrm{Ar})), 7.49$ (td, $J=7.9$ and $1.2 \mathrm{~Hz}, 1 \mathrm{H}, \mathrm{H}-\mathrm{C}(\mathrm{Ar})), 7.36(\mathrm{~d}, J=8.3 \mathrm{~Hz}, 1 \mathrm{H}, \mathrm{H}-$ $\mathrm{C}(\mathrm{Ar})), 7.26(\mathrm{td}, J=7.9$ and $1.1 \mathrm{~Hz}, 1 \mathrm{H}, \mathrm{H}-\mathrm{C}(\mathrm{Ar})), 6.83(\mathrm{~d}, J=8.4 \mathrm{~Hz}, 1 \mathrm{H}, \mathrm{H}-$ $\mathrm{C}(\mathrm{Ar})), 6.59(\mathrm{~d}, J=2.2 \mathrm{~Hz}, 1 \mathrm{H}, \mathrm{H}-\mathrm{C}(2)), 6.53(\mathrm{dd}, J=8.2$ and $2.2 \mathrm{~Hz}, 1 \mathrm{H}, \mathrm{H}-$ C(6) ppm; EI-MS (m/z, \%): 327 (M $\left.\mathrm{M}^{+}, 92\right), 326$ (100), 310 (13), 298 (6), 281 (5), 280 (5), 270 (5), 256 (5), 163 (8), 141 (3), 135 (4).

4-(3-Chlorodibenzo[b,g][1,4,6]oxathiazocin-6-yl)benzene-1,3-diol 12 IR (KBr): $v_{\max }=3255(\mathrm{OH}), 3065(\mathrm{OH}), 1678(\mathrm{C}=\mathrm{N}), 1619(\mathrm{C}=\mathrm{N}), 1594(\mathrm{C}=\mathrm{N}), 1500(\mathrm{C}=\mathrm{C})$, 1472 (C=C), 1452, 1385, 1343, 1308, 1255, 1127, 1099, 1057, 1007, 988, 836, 807, $749 \mathrm{~cm}^{-1}$; ${ }^{1} \mathrm{H}$ NMR (100 MHz, DMSO- $\left.d_{6}\right) \delta: 11.88(\mathrm{~s}, 1 \mathrm{H}, \mathrm{HO}-\mathrm{C}(3)), 10.25$ (s, $1 \mathrm{H}, \mathrm{HO}-\mathrm{C}(1))$, 8.32-8.09 (m, $1 \mathrm{H}, \mathrm{H}-\mathrm{C}(\mathrm{Ar}))$, 7.75-7.68 (m, 1 H, H-C(Ar)), 7.48-7.18 (m, 4 H, H-C(Ar)), 6.95-6.70 (m, 2 H, H-C(Ar)), 6.43-6.34 (m, 2 H, HC(2, 6)) ppm; EI-MS (m/z, \%): 369 (M+10), 333 (5), 257 (11), 253 (100), 244 (89), 220 (26), 218 (82), 202 (6), 192 (13), 183 (6), 162 (28), 137 (83), 109 (12), 91 (9), 80 (60), 77 (5), 69 (7), 65 (15) 63 (16) 53 (9), 52 (7), 44 (6), 39 (11), 36 (4).

\section{Computational methods}

The Clog $\mathrm{P}$ values and molar refractivity MR were calculated using the ChemDraw Ultra 10.0 according to the fragmentation method introduced by Crippen [40]. The tPSA was calculated by Virtual Computational Chemistry Laboratory [41]. The polar surface area (tPSA) was estimated by the atom-based method [42]. 


\section{Biological assays}

\section{Antiproliferative assay}

The following human cell lines were applied in the antiproliferative assay in vitro: T47D (breast cancer), SW707 (rectal adenocarcinoma), and A549 (nonsmall cell lung carcinoma) from the American Type Culture Collection (Rockville, MD, USA), and HCV29T (bladder cancer) from the Fibiger Institute, Copenhagen, Denmark. The SRB test measuring the cell proliferation inhibition in the in vitro culture was applied [43]. The experiments were repeated at least 3 times. The $\mathrm{IC}_{50}$ values were calculated by Cheburator 0.9 .0 software [44]. The details were described previously [45].

\section{Activity of the compounds against phytopathogenic fungi}

In vitro tests estimating the inhibition of mycelium growth in the agar culture medium caused by the compound under investigation were performed. The five strains of phytopathogenic fungi: Alternaria alternata, Botrytis cinerea, Rhizoctonia solani, Fusarium culmorum, and Phytophthora cactorum were used. The solutions (suspensions) were prepared with concentrations making it possible to obtain 200 and $20 \mu \mathrm{g} / \mathrm{mL}$ of the studied substance after dilution with the agar culture medium (PDA). Petri scale pans were used into which the agar culture medium and the studied substance were poured. When the culture medium set, the infectious material of the tested fungus in the form of agar discs overgrown with mycelium were placed at three sites on its surface. After 3-5 days (temperature $22 \pm 1{ }^{\circ} \mathrm{C}$ ) depending on the mycelium culture, the linear growth of the mycelium was measured. The compound action was determined from the percentage of mycelium growth inhibition compared with the control using the equation: $J=(C-T)$ / $C 100 \%$, where $J$ is the percentage of mycelium growth inhibition, $C$ the zone of mycelium growth in the control combination $(\mathrm{mm})$, and $T$ the zone of the mycelium growth in the combination with the compound (mm). Carbendazim (Sarfun $500 \mathrm{SC}$; Organica, Chemical Comp., Nowa Sarzyna, Poland) and procymidone (Sumilex 500 SC; Sumitomo Chemical Comp, Japan) were used as standards. The results are given in the five-degree scale, determining the percentage of mycelium growth inhibition compared with the control. Biological studies were carried out in the Institute of Industrial Organic Chemistry in Warsaw with the SPR/BFF/01/b procedures (certificate GLP-OECD-1997) [36].

\section{Antifungal activity of the compounds against the fungi Candida}

Fifty strains of Candida albicans taken from the mouth cavity of patients suffering from tumors were used as the selective material. Itraconazole and fluconazole were administered for prophylaxis or due to the symptoms of candidosis. The isolates resistant to the antifungal drugs were chosen for the dilution method testing the compounds. In addition, the strain was used for comparison with the American Type 
Culture Collection (University Boulevard, Manassas, VA, USA) C. albicans (ATCC 10231).

Six isolates of non-albicans Candida (two isolates of $C$. tropicalis, one each of $C$. glabrata, $C$. krusei, $C$. paratropicalis, and $C$. tropicalis $)(n=6)$ were tested. The drug resistance by Fungitest ${ }^{\circledR}$ was also determined for them. The MIC values were determined by the agar dilution procedure according to the National Committee for Clinical Laboratory Standards reference document M27 [46]. The details were presented by Matysiak et al. [47]. Itraconazole (Pliva, Krakow, Poland) and fluconazole (Janssen-Cilag) tested under the same experimental conditions were used as the references. MIC values were expressed as the average value from 10 measurements for C. albicans and from 6 for non-albicans Candida.

\section{Results and discussion}

\section{Chemistry}

Using the reaction with sulfinylbis[(2,4-dihydroxyphenyl)methanethione] (STB) suitable nitrogen bases-amines, hydraznes or hydrazides-new compounds with an additional heterocyclic ring have been obtained (Fig. 1; Table 1). Initially, the process was carried out according to the electrophilic substitution to lead to the corresponding thioamides. The final compounds were afforded by the elimination of $\mathrm{HF}$ molecule (compounds $3,4,6,7)$ or $\mathrm{HCl}(\mathbf{8}, \mathbf{1 2})$ leading to thiazole or thiazine rings, respectively. Formation of an azine ring was an effect of $\mathrm{H}_{2} \mathrm{~S}$ elimination (compounds $5, \mathbf{1 0}, \mathbf{1 1}$ ). In the case of the substrates possessing the carbonyl group, cycloaddition took place and a thiazine or thiazole ring was obtained with the additional hydroxyl group $(\mathbf{1}, \mathbf{2})$. Formation of the fused $4 H-3,1$-benzothizin-4-on system was an effect of the elimination of the corresponding amine (9) [5].

The synthesis was performed in methanol under reflux $(2-3 \mathrm{~h})$ with moderate to good yields (64-88\%), as outlined in Fig. 1. The composition and properties of products 1-12 are summarized in Table 2. Purity of the compounds was monitored by the reversed-phase HPLC (CP-18, methanol-water mobile phase). The log $k$ values of the compounds for the selected system are collected in Table 2. The other analytical data of the compounds confirmed the proposed constructions.

The $\mathrm{OH}$ substituents of the compounds were usually registered as broad singlets at ca. $10-12.5 \mathrm{ppm}$ by ${ }^{1} \mathrm{H}$ NMR spectroscopy. OH protons were exchangeable in $\mathrm{D}_{2} \mathrm{O}$. Similar data for other derivatives with the benzenediol moiety were obtained [40]. A strong band in the region of about $1630-1600 \mathrm{~cm}^{-1}$ was recorded which corresponds to the $v(\mathrm{C}=\mathrm{N})$ bond in the IR spectra. The bands in the range of ca. $3500-3150 \mathrm{~cm}^{-1}$ confirmed the presence of $\mathrm{OH}$ groups. The $\mathrm{C}=\mathrm{O}$ moiety was observed for compounds $\mathbf{1}$ and 10. In the case of compounds $\mathbf{2}$ and $\mathbf{5}$, the carbonyl group of the substrates was not observed. In the EI-MS, the molecular ion peak $\mathrm{M}^{+}$ of varying intensity was registered. 
Table 1 Structures of the compounds and substrates applied in the synthesis

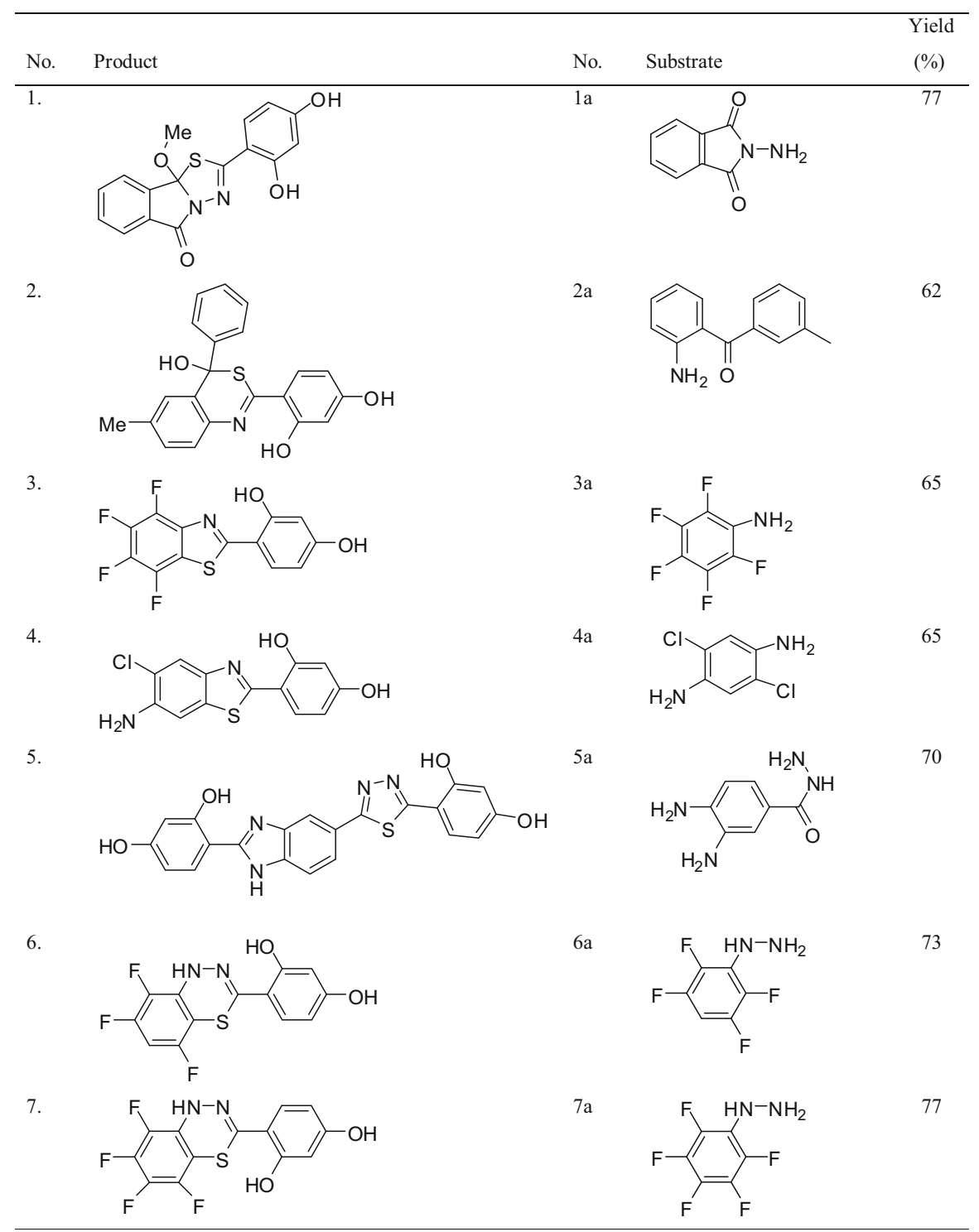


Table 1 continued

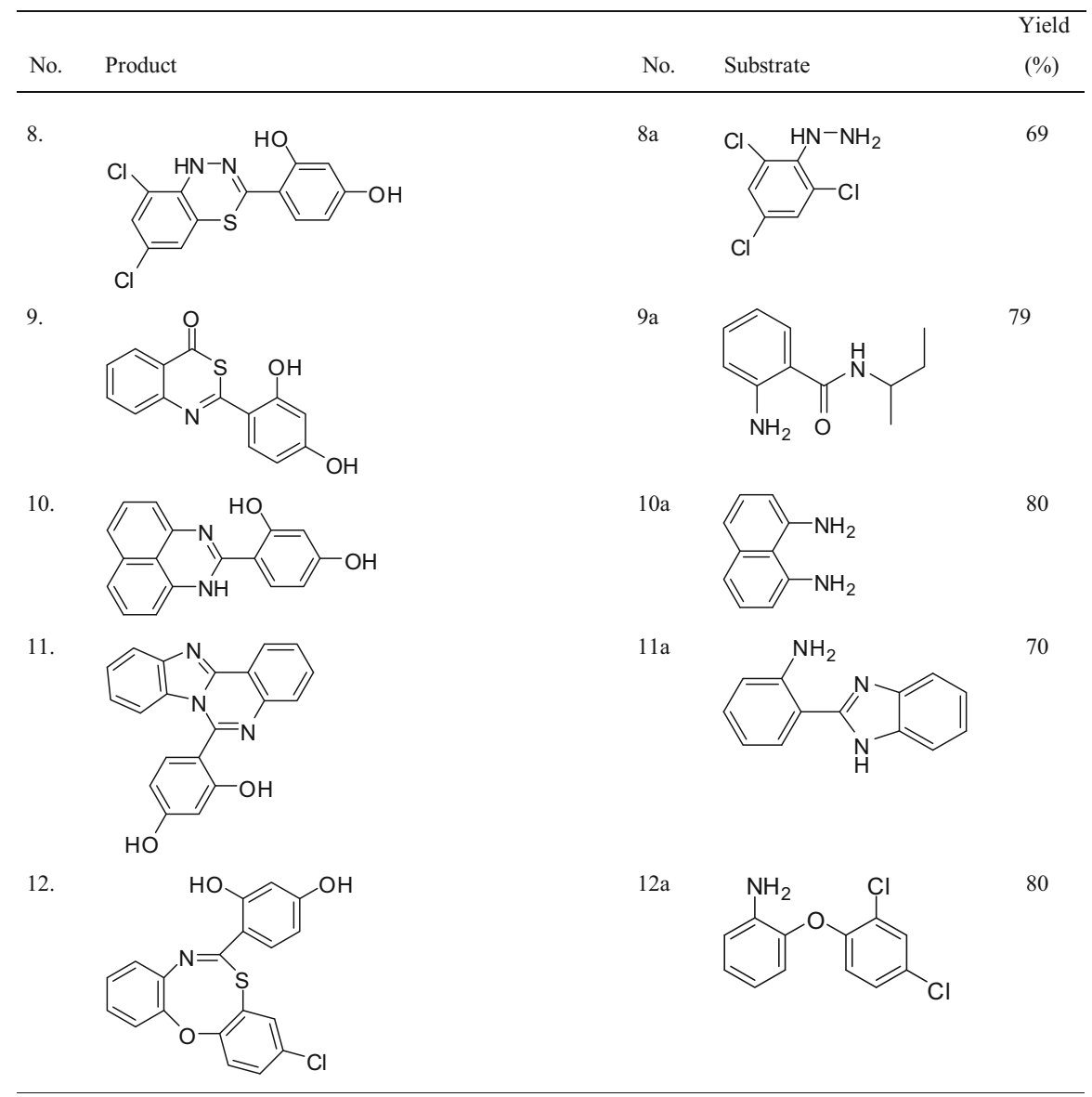

\section{Biological activity}

Cytotoxic activity in vitro of two compounds, $\mathbf{3}$ and 11, was assessed against four human cancer cells. Their potency was expressed as $\mathrm{IC}_{50}[\mu \mathrm{M}]$ which is the concentration of the substance that inhibited the proliferation rate of tumour cells by $50 \%$ as compared to the untreated control cells. The results of the tests are presented in Table 3. They show that both compounds display substantial activity against all studied cells, similar to that of cisplatin.

Antifungal potency of the selected compounds was assessed in vitro against five strains of phytopathogenic fungi (Table 4). The research was carried out at two different concentrations: 20 and $200 \mu \mathrm{g} / \mathrm{mL}$. They show that the antifungal potency of compounds is varied, and that the highest activity was found for compound 7 with the 5,6,7,8-tetrafluoro- $1 H$-benzo[ $e][1,3,4]$ thiadiazine ring. At the concentrations of 200 and $20 \mu \mathrm{g} / \mathrm{mL}$ the derivative showed fungistatic action against $A$. 
Table 2 Characterization data of compounds 1-12

\begin{tabular}{|c|c|c|c|c|c|c|c|}
\hline \multirow[t]{2}{*}{ No. } & \multirow[t]{2}{*}{ Formula } & \multirow[t]{2}{*}{$M$} & \multicolumn{3}{|c|}{$\begin{array}{l}\text { Elemental analysis } \\
\text { (calcd.)/(found)/ \% }\end{array}$} & \multirow[t]{2}{*}{ M.p. ${ }^{\circ} \mathrm{C}$} & \multirow[t]{2}{*}{$\log k$} \\
\hline & & & $\mathrm{C}$ & $\mathrm{H}$ & $\mathrm{N}$ & & \\
\hline \multirow[t]{2}{*}{1.} & \multirow[t]{2}{*}{$\mathrm{C}_{16} \mathrm{H}_{12} \mathrm{~N}_{2} \mathrm{O}_{4} \mathrm{~S}$} & \multirow[t]{2}{*}{328.34} & 58.53 & 3.68 & 8.53 & \multirow[t]{2}{*}{$193-195$} & \multirow[t]{2}{*}{$0.027^{\mathrm{b}}$} \\
\hline & & & 58.60 & 3.66 & 8.56 & & \\
\hline \multirow[t]{2}{*}{2.} & \multirow[t]{2}{*}{$\mathrm{C}_{21} \mathrm{H}_{17} \mathrm{NO}_{3} \mathrm{~S}$} & \multirow[t]{2}{*}{363.43} & 69.40 & 4.71 & 3.85 & \multirow[t]{2}{*}{$123-124$} & \multirow[t]{2}{*}{$-0.277^{\mathrm{b}}$} \\
\hline & & & 69.51 & 4.70 & 3.87 & & \\
\hline \multirow[t]{2}{*}{3.} & \multirow[t]{2}{*}{$\mathrm{C}_{13} \mathrm{H}_{5} \mathrm{~F}_{4} \mathrm{NO}_{2} \mathrm{~S}$} & \multirow[t]{2}{*}{315.24} & 49.53 & 1.60 & 4.44 & \multirow[t]{2}{*}{$197-199$} & \multirow[t]{2}{*}{$0.313^{\mathrm{b}}$} \\
\hline & & & 49.60 & 1.59 & 4.46 & & \\
\hline \multirow[t]{2}{*}{4.} & \multirow[t]{2}{*}{$\mathrm{C}_{13} \mathrm{H}_{9} \mathrm{~N}_{2} \mathrm{O}_{2} \mathrm{SCl}$} & \multirow[t]{2}{*}{292.74} & 53.34 & 3.10 & 9.57 & \multirow[t]{2}{*}{$246-248$} & \multirow[t]{2}{*}{$0.440^{\mathrm{b}}$} \\
\hline & & & 53.46 & 3.09 & 9.60 & & \\
\hline \multirow[t]{2}{*}{5.} & \multirow[t]{2}{*}{$\mathrm{C}_{21} \mathrm{H}_{14} \mathrm{~N}_{4} \mathrm{O}_{4} \mathrm{~S}$} & \multirow[t]{2}{*}{418.43} & 60.28 & 3.37 & 13.39 & \multirow[t]{2}{*}{$220-221$} & \multirow[t]{2}{*}{$-0.357^{\mathrm{a}}$} \\
\hline & & & 60.21 & 3.35 & 13.43 & & \\
\hline \multirow[t]{2}{*}{6.} & \multirow[t]{2}{*}{$\mathrm{C}_{13} \mathrm{H}_{7} \mathrm{~F}_{3} \mathrm{~N}_{2} \mathrm{O}_{2} \mathrm{~S}$} & 312.27 & 50.00 & 2.26 & 8.97 & $146-147$ & $-1.107^{\mathrm{a}}$ \\
\hline & & & 49.88 & 2.27 & 9.00 & & \\
\hline 7. & $\mathrm{C}_{13} \mathrm{H}_{6} \mathrm{~F}_{4} \mathrm{~N} 2 \mathrm{O}_{2} \mathrm{~S}$ & 330.25 & 47.28 & 1.83 & 8.48 & $123-125$ & $-0.570^{\mathrm{a}}$ \\
\hline & & & 47.35 & 1.84 & 8.44 & & \\
\hline 8. & $\mathrm{C}_{13} \mathrm{H}_{8} \mathrm{~N}_{2} \mathrm{O}_{2} \mathrm{SCl}$ & 327.19 & 47.72 & 2.46 & 8.56 & $185-186$ & $-0.402^{\mathrm{a}}$ \\
\hline & & & 47.80 & 2.45 & 8.59 & & \\
\hline 10. & $\mathrm{C}_{17} \mathrm{H}_{12} \mathrm{~N}_{2} \mathrm{O}_{2}$ & 276.29 & 73.90 & 4.38 & 10.14 & $210-212$ & $-0.175^{\mathrm{a}}$ \\
\hline & & & 74.01 & 4.40 & 10.10 & & \\
\hline 11. & $\mathrm{C}_{20} \mathrm{H}_{13} \mathrm{~N}_{3} \mathrm{~S}$ & 327.10 & 73.38 & 4.00 & 12.84 & 294-296 & $-0.091^{\mathrm{a}}$ \\
\hline & & & 73.30 & 4.02 & 12.80 & & \\
\hline 12. & $\mathrm{C}_{19} \mathrm{H}_{12} \mathrm{ClNO}_{3} \mathrm{~S}$ & 369.82 & 61.71 & 3.27 & 3.45 & $210-212$ & $-0.175^{\mathrm{a}}$ \\
\hline & & & 59.70 & 3.25 & 3.47 & & \\
\hline
\end{tabular}

${ }^{\mathrm{a}}$ The $\log k$ values for $80 \%$ of $\mathrm{MeOH}(\mathrm{v} / \mathrm{v})$ in the mobile phase

${ }^{\mathrm{b}} \mathrm{The} \log k$ values for $65 \%$ of $\mathrm{MeOH}(\mathrm{v} / \mathrm{v})$ in the mobile phase

Table 3 Antiproliferative activity of compounds $\mathbf{3}$ and $\mathbf{1 1}$ against human cancer cell lines

\begin{tabular}{|c|c|c|c|c|}
\hline \multirow[t]{2}{*}{ Compound } & \multicolumn{4}{|c|}{ Cell line $/ \mathrm{IC}_{50}^{\mathrm{a}} /(\mu \mathrm{M})$} \\
\hline & HCV29T & A 549 & $\mathrm{~T} 47 \mathrm{D}$ & SW 707 \\
\hline 3. & $28.30 \pm 8.63$ & $19.38 \pm 3.87$ & $16.94 \pm 5.14$ & $19.60 \pm 4.54$ \\
\hline 11. & $7.28 \pm 2.04$ & $5.56 \pm 3.73$ & $10.73 \pm 0.80$ & $13.85 \pm 0.61$ \\
\hline Cisplatin & $10.33 \pm 3.20$ & $22.57 \pm 17.89$ & $21.56 \pm 7.57$ & $34.77 \pm 16.53$ \\
\hline
\end{tabular}

${ }^{\mathrm{a}} I C_{50}$ indicates the compound concentration that inhibits the proliferation rate of tumor cells by $50 \%$ as compared to the control untreated cells. The values are the mean $\pm \mathrm{SD}$ of nine independent experiments 
Table 4 Antifungal potency of compounds against phytopathogenic fungi

\begin{tabular}{|c|c|c|c|c|c|c|c|c|c|c|}
\hline \multirow[t]{3}{*}{ Compound } & \multicolumn{10}{|c|}{ Estimation of mycelium growth inhibition $\mathrm{a} /(\mu \mathrm{g} / \mathrm{mL})$} \\
\hline & \multicolumn{2}{|c|}{ A. alternata } & \multicolumn{2}{|c|}{ B. cinerea } & \multicolumn{2}{|c|}{ R. solani } & \multicolumn{2}{|c|}{ F. culmorum } & \multicolumn{2}{|c|}{ P. cactorum } \\
\hline & 200 & 20 & 200 & 20 & 200 & 20 & 200 & 20 & 200 & 20 \\
\hline 2. & 1 & 0 & 0 & 0 & 0 & 0 & 0 & 0 & 0 & 0 \\
\hline 4. & 2 & 1 & 2 & 1 & 0 & 0 & 2 & 0 & 2 & 1 \\
\hline 5. & 0 & 0 & 0 & 0 & 1 & 0 & 0 & 0 & 0 & 0 \\
\hline 7. & 2 & 1 & 2 & 1 & 2 & 0 & 2 & 1 & 2 & 0 \\
\hline 9. & 2 & 1 & 2 & 0 & 2 & 0 & 0 & 0 & 1 & 0 \\
\hline 10. & 0 & 0 & 0 & 0 & 0 & 0 & 0 & 0 & 0 & 0 \\
\hline Carbendazim & $-{ }^{b}$ & $-\mathrm{b}$ & $-\mathrm{b}$ & $-{ }^{b}$ & 3 & 3 & 3 & 3 & 3 & 3 \\
\hline Procymidone & 2 & 2 & 3 & 3 & $-{ }^{b}$ & $-\mathrm{b}$ & $-\mathrm{b}$ & $-\mathrm{b}$ & $-{ }^{b}$ & $-\mathrm{b}$ \\
\hline
\end{tabular}

${ }^{\mathrm{a}}$ The results are given in the five-degree scale determining the percentage of mycelium growth inhibition compared with the control: $0=0-20 \% ; 1=21-40 \% ; 2=41-60 \% ; 3=61-80 \% ; 4=81-100 \%$

${ }^{\mathrm{b}}$ Study was not performed

alternate, P. cactorum and B. cinerea at the levels of $41-60 \%$ and $21-40 \%$, respectively. The compounds under consideration show lower potency compared to the previously described analogs with the 2,4-dihydroxyphenyl moiety [36].

Antifungal activity of the compounds against pathogenic fungi was also estimated. It was expressed as the average MIC values against several clinical strains of $C$. albicans and non-albicans Candida as well as against the reference strain of $C$. albicans (Table 5). The results show that the non-albicans Candida

Table 5 Antifungal activity against $C$. albicans and non-albicans Candida strains expressed in the average MIC values $(\mu \mathrm{g} / \mathrm{mL})^{\mathrm{a}}$

\begin{tabular}{lccc}
\hline Compound & C. $^{\text {albicans ATCC } 10231^{\mathrm{b}}}$ & ${\text { C. } \text { albicans }^{\mathrm{c}}(n=10)}$ & Non-albicans Candida $^{\mathrm{d}}(n=6)$ \\
\hline 1. & $100.0 \pm 0.0$ & $95.0 \pm 15.8$ & $75.0 \pm 38.7$ \\
4. & $200.0 \pm 0.0$ & $200.0 \pm 0.0$ & $83.3 \pm 60.6$ \\
6. & $100.0 \pm 0.0$ & $90.0 \pm 45.9$ & $23.96 \pm 15.0$ \\
7. & $50.0 \pm 0.0$ & $50.0 \pm 0.0$ & $47.9 \pm 30.01$ \\
$\mathbf{8 .}$ & $200.0 \pm 0.0$ & $100.0 \pm 0.0$ & $100.0 \pm 0.0$ \\
12. & $100.0 \pm 0.0$ & $70.0 \pm 25.2$ & $83.3 \pm 60.6$ \\
Itraconazole & $200.0 \pm 0.0$ & $47.5 \pm 7.9$ & $27.5 \pm 7.9$ \\
Fluconazole & $200.0 \pm 0.0$ & $27.5 \pm 7.9$ & $12.5 \pm 0.0$
\end{tabular}

${ }^{\mathrm{a}} M I C$ the minimal inhibitory concentration caused full inhibition of growth in relation to the control $(\mu \mathrm{g} /$ $\mathrm{mL})$

${ }^{\mathrm{b}} \mathrm{MIC} \pm \mathrm{SD}$ (mean \pm standard deviation of three independent experiments)

${ }^{\mathrm{c}} \mathrm{MIC} \pm \mathrm{SD}$ (MIC values expressed as the average value from 10 isolates \pm standard deviation)

${ }^{\mathrm{d}} \mathrm{MIC} \pm \mathrm{SD}$ (MIC values expressed as the average value from 6 isolates \pm standard deviation) 
Table 6 Molecular descriptors in silico of compounds

\begin{tabular}{lllllllll}
\hline Compound & HBD & HBA & C logP & MlogP & NR & RB & tPSA $\left(\AA^{2}\right)$ & MR $\left(\mathrm{cm}^{3} / \mathrm{mol}\right)$ \\
\hline 1. & 2 & 6 & 2.00 & 1.96 & 4 & 2 & 82.36 & 84.67 \\
2. & 3 & 4 & 3.39 & 2.91 & 4 & 2 & 73.05 & 104.09 \\
3. & 2 & 3 & 3.36 & 2.93 & 3 & 1 & 53.35 & 68.76 \\
4. & 4 & 4 & 3.21 & 1.86 & 3 & 1 & 79.37 & 76.57 \\
5. & 5 & 8 & 2.81 & 1.33 & 5 & 3 & 135.38 & 115.72 \\
6. & 3 & 4 & 1.92 & 2.80 & 3 & 1 & 64.85 & 72.74 \\
7. & 3 & 4 & 1.92 & 2.93 & 3 & 1 & 64.85 & 73.14 \\
8. & 3 & 4 & 2.99 & 2.93 & 3 & 1 & 64.85 & 80.73 \\
9. & 2 & 4 & 1.29 & 1.78 & 3 & 1 & 69.89 & 71.81 \\
10. & 3 & 4 & 4.49 & 3.00 & 4 & 1 & 64.85 & 80.43 \\
11. & 2 & 5 & 4.12 & 3.58 & 5 & 1 & 70.65 & 93.19 \\
12. & 2 & 4 & 5.89 & 3.08 & 4 & 1 & 66.49 & 97.34 \\
\hline
\end{tabular}

$H B D$ the number of $\mathrm{H}$-bond donors, $H B A$ the number of $\mathrm{H}$-bond acceptors, $C \log P$ the octanol-water partition coefficients, $M \log P$ the Moriguchi octanol-water partition coefficient, $R B$ the number of rotatable bonds, $N R$ the number of rings; $t P S A$ the polar surface area, $M R$ the molar refractivity

clinical isolates are more sensitive to the considered compound than those of $C$. albicans. The strongest antifungal activity was observed for compound 7 .

To estimate drug-likeness of the compounds, their molecular descriptors were calculated in silico (Table 6) and Lipinki's rule of five was applied [48]. The partition coefficient of compounds was determined in two different ways: $\log \mathrm{P}$ and clog $\mathrm{P}$ (Table 6). The results show that the compounds with the exception of compound 12 meet the Lipinki's criterion and possess drug-like properties.

Open Access This article is distributed under the terms of the Creative Commons Attribution 4.0 International License (http://creativecommons.org/licenses/by/4.0/), which permits unrestricted use, distribution, and reproduction in any medium, provided you give appropriate credit to the original author(s) and the source, provide a link to the Creative Commons license, and indicate if changes were made.

\section{References}

1. R. Fringuelli, L. Milanese, F. Schiaffella, Mini Rev. Med. Chem. 5, 1061 (2005)

2. J. Wang, Q.L. Xu, J.M. Li, E.L. Zhang, M.H. Hu, W.F. Ye, W.J. Huang, Chin. J. Org. Chem. 34, $2040(2014)$

3. S.I. Mohammed, B.A. Craig, A.J. Mutsaers, N.W. Glickman, P.W. Snyder, A.E. deGortari, D.L. Schlittler, D.L. Schlittler, K.T. Coffman, P.L. Bonney, D.W. Knapp, Mol. Cancer Ther. 2, 183 (2003)

4. A.N. Matralis, E.I. Bavavea, S. Incerpi, J.Z. Pedersen, A.P. Kourounakis, Curr. Med. Chem. 24, 1214 (2017)

5. J. Matysiak, Bioorg. Med. Chem. 14, 2613 (2006)

6. D.A. Lega, V.P. Chernykh, L. Zaprutko, A.K. Gzella, L.A. Shemchuk, Chem. Heterocycl. Compd. 53, 219 (2017)

7. M. Shafiq, I.U. Khan, M.N. Arshad, W.A. Siddiqui, Asian J. Chem. 23, 2101 (2011)

8. B.S. Rathore, M. Kumar, Bioorg. Med. Chem. 14, 5678 (2006)

9. B.J. Khairnar, R.S. Salunke, P.B. Patil, S.A. Patil, R.J. Kapade, P.S. Girase, B.R. Chaudhari, E-J. Chem. 9, 318 (2012) 
10. S. Mor, P. Pahal, B. Narasimhan, Eur. J. Med. Chem. 53, 176 (2012)

11. A. Zieba, M. Latocha, A. Sochanik, Med. Chem. Res. 22, 4158 (2013)

12. M. Jelen, K. Pluta, M. Zimecki, B. Morak-Mlodawska, J. Artym, M. Kocieba, Eur. J. Med. Chem. 89, 411 (2015)

13. K.G. Desai, K.R. Desai, Bioorg. Med. Chem. 14, 8271 (2006)

14. C. Gill, G. Jadhav, M. Shaikh, R. Kale, A. Ghawalkar, D. Nagargoje, M. Shiradkar, Bioorg. Med. Chem. Lett. 18, 6244 (2008)

15. K.F. Ansari, C. Lal, J. Chem. Soc. 121, 1017 (2009)

16. K.F. Ansari, C. Lal, Eur. J. Med. Chem. 44, 4028 (2009)

17. A. Kitamura, K. Someya, M. Hata, R. Nakajima, M. Takemura, Antimicrob. Agents Chemother. 53, 670 (2009)

18. H. Goker, D.W. Boykin, S. Yildiz, Bioorg. Med. Chem. 13, 1707 (2005)

19. C.B. Zhang, Y. Liu, Z.F. Liu, S.Z. Duan, M.Y. Li, W. Chen, Y. Li, H.B. Zhang, X.D. Yang, Bioorg. Med. Chem. Lett. 27, 1808 (2017)

20. B. Soni, M.S. Ranawat, R. Sharma, A. Bhandari, S. Sharma, Eur. J. Med. Chem. 45, 2938 (2010)

21. S. Rubino, R. Busa, A. Attanzio, R. Alduina, V. Di Stefano, M.A. Girasolo, S. Orecchio, L. Tesoriere, Bioorg. Med. Chem. 25, 2378 (2017)

22. S. Maddila, S. Gorle, N. Seshadri, P. Lavanya, S.B. Jonnalagadda, Arab. J. Chem. 9, 681 (2016)

23. M. Singh, S.K. Singh, M. Gangwar, G. Nath, S.K. Singh, RSC Adv. 4, 19013 (2014)

24. A. Belal, M.A. Abdelgawad, Res. Chem. Intermediat. 43, 3859 (2017)

25. A.K. El-Damasy, J.H. Lee, S.H. Seo, N.C. Cho, A.N. Pae, G. Keum, Eur. J. Med. Chem. 115, 201 (2016)

26. B. Mavroidi, M. Sagnou, K. Stamatakis, M. Paravatou-Petsotas, M. Pelecanou, C. Methenitis, Inorganica Chim. Acta 444, 63 (2016)

27. G.J. Kumar, S.N. Kumar, D. Thummuri, L.B.S. Adari, V.G.M. Naidu, K. Srinivas, V.J. Rao, Med. Chem. Res. 24, 3991 (2015)

28. S.Z. Zhao, L.Y. Zhao, X.Q. Zhang, C.C. Liu, C.Z. Hao, H.L. Xie, B. Sun, D.M. Zhao, M.S. Cheng, Eur. J. Med. Chem. 123, 514 (2016)

29. N.H. Cano, M.S. Ballari, A.G. Lopez, A.N. Santiago, J. Agric. Food Chem. 63, 3681 (2015)

30. Y. Liu, Y. Wang, G.Q. Dong, Y.Q. Zhang, S.C. Wu, Z.Y. Miao, J.Z. Yao, W.N. Zhang, C.Q. Sheng, Medchemcomm 4, 1551 (2013)

31. S. Gupta, N. Ajmera, N. Gautam, R. Sharma, D.C. Gautam, Indian J. Chem. Sect B 48, 853 (2009)

32. R.K. Gill, G. Singh, A. Sharma, P.M.S. Bedi, A.K. Saxena, Med. Chem. Res. 22, 4211 (2013)

33. T.H. Al-Tel, R.A. Al-Qawasmeh, R. Zaarour, Eur. J. Med. Chem. 46, 1874 (2011)

34. J. Matysiak, A. Niewiadomy, B. Senczyna, A. Zabinska, J.K. Rozylo, J. AOAC Int. 87, 579 (2004)

35. J. Matysiak, A. Skrzypek, M. Karpinska, U. Glaszcz, A. Niewiadomy, B. Paw, B. Senczyna, J. Wietrzyk, D. Klopotowska, J. Enzyme Inhib. Med. Chem. 31, 166 (2016)

36. J. Legocki, J. Matysiak, A. Niewiadomy, M. Kostecka, J. Agric. Food Chem. 51, 362 (2003)

37. J. Matysiak, A. Niewiadomy, B. Paw, I. Dybala, Arch. Pharm. (Weinheim) 344, 340 (2011)

38. J. Matysiak, R. Los, A. Malm, M.M. Karpinska, U. Glaszcz, B. Rajtar, M. Polz-Dacewicz, M. Trojanowska-Wesolowska, A. Niewiadomy, Arch. Pharm. (Weinheim) 345, 302 (2012)

39. J. Matysiak, A. Niewiadomy, Bioorg. Med. Chem. 11, 2285 (2003)

40. A.K. Ghose, G.M. Crippen, J. Chem. Inf. Comput. Sci. 27, 21 (1987)

41. http://www.vcclab.org

42. P. Ertl, B. Rohde, P. Selzer, J. Med. Chem. 43, 3714 (2000)

43. P. Skehan, R. Storeng, D. Scudiero, A. Monks, J. McMahon, D. Vistica, J.T. Warren, H. Bokesch, S. Kenney, M.R. Boyd, J. Natl Cancer Inst. 82, 1107 (1990)

44. D. Nevozhay, PLoS ONE 9, e106186 (2014)

45. J. Matysiak, A. Opolski, Bioorg. Med. Chem. 14, 4483 (2006)

46. Clinical and Laboratory Standards Institute. Reference Method for Broth Dilution Antifungal Susceptibility Testing of Yeasts; Approved Standard. CLSI document M27-A. (Clinical and Laboratory Standards Institute, Wayne, 1997)

47. A. Niewiadomy, A. Skrzypek, J. Matysiak, U. Glaszcz, J. Wietrzyk, E. Krajewska-Kulak, Acta Pol. Pharm. 72, 943 (2015)

48. C.A. Lipinski, Drug Discov. Today Technol. 1, 337 (2004) 